\title{
Complex E\&S Modeling for Magnetic Field Analysis Taking Account of 2-D Vector Magnetic Properties
}

\author{
K. Nakanoue, S. Urata, Y. Nakahata, T. Todaka, M. Enokizono, and H. Shimoji \\ Faculty of Engineering, Oita Univ., 700 Dannoharu, Oita 870-1192, Japan
}

\begin{abstract}
2-D vector magnetic properties accurately represent the magnetic properties of various kinds of electrical steel sheets, because they can represent an alternating magnetic field in any direction and a rotating magnetic field by using the relationship between the flux density vector $B$ and the field strength vector $H$. E\&S modeling is proposed as a method for representing 2 -D vector magnetic properties in magnetic field analyses. However, the E\&S modeling used in magnetic field analyses is very time-consuming. To solve this problem, we propose complex E\&S modeling on the assumption that both the flux density and field strength waveforms are sinusoidal. We carried out FEM analyses taking account of complex E\&S modeling. Finally, we compared the analyses results considering complex E\&S modeling with those of conventional E\&S modeling, and made clear the efficiency of complex E\&S modeling.
\end{abstract}

Key words: E\&S modeling, 2-D vector magnetic properties, complex magnetic permeability, hysteresis loop, effective magnetic reluctivity coefficient, effective magnetic hysteresis coefficient

\section{2 次元ベクトル磁気特性を考慮した磁界解析のための複素 E\&S モデル} 中ノ上 賢治・浦田 信也・中畑 和・戶高 孝・榎園 正人・下地 広泰 大分大学工学部, 大分市旦野原 700 ( T 870-1192)

\section{1.はじめに}

近年の地球温暖化に伴い, 京都義定書などをはじめ , 世界中で 省エネを進める動きが活発になってきている.日本国内において も 1998年に省工ネ法の大幅な改正力行われ，この改正の中にはト ップランナー方式という新しい制度も盛り込まれており，電気機 器の高効率化力求められている．電気機器の更なる高効率化を実 現するためには機器の磁気特性を詳細に理解する必要があり，機 器の開発口設計において磁界解析技術は重要なものとなってきて いる. 現在磁界解析においては, 単一方向の交番磁気特性を考慮 したものか主流であるが, 本来べクトル量であるはずの磁気の世 界を表現するには不十分とされている.この問題を解決するため， 磁束密度と磁界強度をべクトル量として評価する 2 次元ベクトル 磁気特性力提案されているํ).2次元べクトル磁気特性は磁束密度 と磁界強度をべクトル量として評価しているので, 材料の磁気異 方性を表現することかでき，鉄損分布を直接計算することもでき る.この2 次元べクトル磁気特性を磁界解析に取り入れることが できれば，更なる高効率電気機器開発への大きな助力となると考 えられる．光こで著者らは，磁界解析に2 次元べクトル磁気特性 を考慮する手法として E\&Sモデルを提案した ${ }^{2,3}$. E ES モデルは， 磁界強度波形を磁束密度波形の同相分と 90 度位相の異なる成分を 用いて表現し，位相ずれて損失を表現することか特徵となってい る.しかしながら , 従来の E\&S モデルは実測した材料特性のデー タベースを基とする手法であり，高磁束密度領域の非線形性の強 い問題では収束性か悪く多大の計算時間を要するため, 最適設計 問題への適用力困難であった . 最適設計において効率を向上させ るためにはまず近似的な計算によってある程度の傾向を把握する ことか重要であり，乥の後精確な計算を行うことか望ましい，仮 に磁束密度と磁界強度か正弦波であれば, 正弦波理論から複素量 を用いることか可能であり，磁気抵抗を複素磁気抵抗て取り扱う
ことができる，本論文では，磁束密度およひ磁界強度波形の歪み を無視し, 光れらの基本波成分の関係を複素数で表現した E\&S モ デルを複素 E $\& S$ モデルと呼称する. 複素 E\&S モデルは 1 周期を 1 回の計算て解くことか可能であり，従来の時間ステップの E\&S モ デルに比べて精度は落ちるものの高速に近似解を求めることかで きる . もしこの複素 E\&S モデルを実用的な簡易設計ツールとして 確立することができれば, 短時間で多数のモデル条件を解析する 最適設言十問題等への適用が可能となり，2次元べクトル磁気特性 を考慮した機器設計か容易となる。

本論文ては複素 E\&S モデルの定義式を示し，従来の E\&S モデル の解析結果と比較して, 光の妥当性およひ有効性を示す.

\section{2 次元べクトル磁気特性測定磁束条件}

Fig. 1 に2次元べクトル磁気特性を定義するための磁束条件を 示す.磁束条件は, 最大磁束密度 $B_{\max }$,田延方向(磁化容易軸方向) と最大磁束密度方向のなす角度 $\theta_{B}$,および最大磁束密度と最小磁 束密度の大きさの比 $\alpha$ のつのパラメータにて支配される ${ }^{4), 5)} . \alpha$ $=0$ の場合に交番磁束条件となり， $\alpha=1.0$ の場合に真円の回転磁 束条件となる .

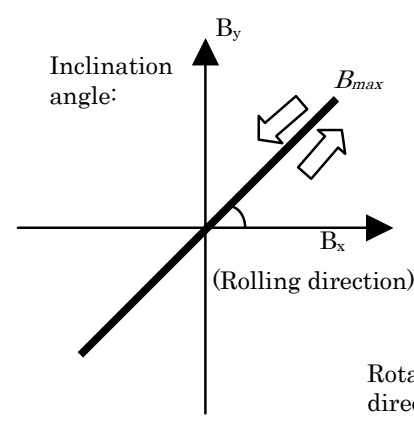

(a) Alternating flux condition

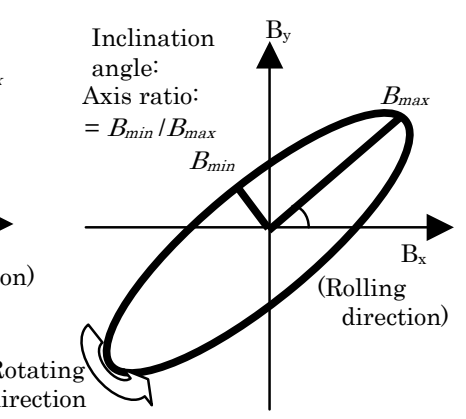

(b) Rotating flux condition
Fig. 1 Representation of alternating and flux conditions. 


\section{3. 定義式と定式化}

\section{1 従来のE \& S モデル}

従来のE\&S モデルの定義式を以下に示す ${ }^{2}$.

$$
\begin{aligned}
& H_{x}=\bar{v}_{x r} B_{x}+\bar{v}_{x i} \frac{\partial B_{x}}{\partial t} \\
& H_{y}=\bar{v}_{y r} B_{y}+\bar{v}_{y i} \frac{\partial B_{y}}{\partial t}
\end{aligned}
$$

ここで， $\bar{v}_{x r}, \bar{v}_{y r}$ は光れ光れX方向，Y方向の磁気抵抗係数を表 し， $\bar{v}_{x i} ， \bar{v}_{y i}$ は光れ光れ $\mathrm{X}$ 方向，Y方向の磁気ヒステリシス伱数 を表す.磁气抵抗係数と磁気ヒステリシス係数は実測データから 求められ，磁束条件のパラメータである $B_{\max }, \theta_{B}, \alpha$ の関数とし てデータベース化される .

\section{2 複素E\&S モデル}

式(1)，(2)において磁束密度と磁界強度力正弦波であれば, $\partial / \partial t$

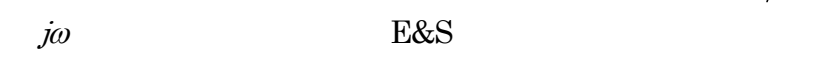
きる

$$
\begin{aligned}
& \dot{H}_{x}=\bar{v}_{x r} \dot{B}_{x}+j \omega \bar{v}_{x i} \dot{B}_{x} \\
& \dot{H}_{y}=\bar{v}_{y r} \dot{B}_{y}+j \omega \bar{v}_{y i} \dot{B}_{y}
\end{aligned}
$$

ドット(口)は複素量を表す。

ここで，磁束密度を式(5)，(6)にて，磁界強度を式（7)，(8)にて表 現する. Fig. 2 に $\dot{B}_{x}$ と $\dot{H}_{x}$ の位相関係を示す .

$$
\begin{aligned}
& \dot{B}_{x}=\left|\dot{B}_{x}\right| \mathrm{e}^{j \theta_{B_{x}}}=\left|\dot{B}_{x}\right|\left(\cos \left(\theta_{B_{x}}\right)+j \sin \left(\theta_{B_{x}}\right)\right) \\
& \dot{B}_{y}=\left|\dot{B}_{y}\right| \mathrm{e}^{j \theta_{B_{y}}}=\left|\dot{B}_{y}\right|\left(\cos \left(\theta_{B_{y}}\right)+j \sin \left(\theta_{B_{y}}\right)\right) \\
& \dot{H}_{x}=\left|\dot{H}_{x}\right| \mathrm{e}^{j \theta_{H_{x}}}=\left|\dot{H}_{x}\right|\left(\cos \left(\theta_{H_{x}}\right)+j \sin \left(\theta_{H_{x}}\right)\right) \\
& \dot{H}_{y}=\left|\dot{H}_{y}\right| \mathrm{e}^{j \theta_{H_{y}}}=\left|\dot{H}_{y}\right|\left(\cos \left(\theta_{H_{y}}\right)+j \sin \left(\theta_{H_{y}}\right)\right)
\end{aligned}
$$

磁气抵抗係数および磁気ヒステリシス係数は次式て定義できる．

$$
\begin{aligned}
& \bar{v}_{x r}=\frac{\left|\dot{H}_{x}\right|}{\left|\dot{B}_{x}\right|} \cos \left(\theta_{H_{x}}-\theta_{B_{x}}\right)=\frac{\left|\dot{H}_{x}\right|}{\left|\dot{B}_{x}\right|} \cos \left(\theta_{B H_{x}}\right) \\
& \bar{V}_{x i}=\frac{\left|\dot{H}_{x}\right|}{\omega\left|\dot{B}_{x}\right|} \sin \left(\theta_{H_{x}}-\theta_{B_{x}}\right)=\frac{\left|\dot{H}_{x}\right|}{\omega\left|\dot{B}_{x}\right|} \sin \left(\theta_{B H_{x}}\right) \\
& \bar{v}_{y r}=\frac{\left|\dot{H}_{y}\right|}{\left|\dot{B}_{y}\right|} \cos \left(\theta_{H_{y}}-\theta_{B_{y}}\right)=\frac{\left|\dot{H}_{y}\right|}{\left|\dot{B}_{y}\right|} \cos \left(\theta_{B H_{y}}\right) \\
& \bar{v}_{y i}=\frac{\left|\dot{H}_{y}\right|}{\omega\left|\dot{B}_{y}\right|} \sin \left(\theta_{H_{y}}-\theta_{B_{y}}\right)=\frac{\left|\dot{H}_{y}\right|}{\omega\left|\dot{B}_{y}\right|} \sin \left(\theta_{B H_{y}}\right)
\end{aligned}
$$

\section{3 支配方程式}

複素 $\mathrm{E} \& \mathrm{~S}$ モデルを考慮した支配方程式は次式となる．

$$
\begin{aligned}
\frac{\partial}{\partial x}\left(\bar{v}_{y r} \frac{\partial \dot{A}_{z}}{\partial x}\right. & \left.+j \omega \bar{v}_{y i} \frac{\partial \dot{A}_{z}}{\partial x}\right) \\
+ & \frac{\partial}{\partial y}\left(\bar{v}_{x r} \frac{\partial \dot{A}_{z}}{\partial y}+j \omega \bar{v}_{x i} \frac{\partial \dot{A}_{z}}{\partial x}\right)=-\dot{J}_{0 z}
\end{aligned}
$$

ここで, $\dot{A}_{z}$ は複素ベクトルポテンシャルのZ方向成分, $\dot{J}_{0 z}$ は複 素電流密度のZ方向成分とする．

\section{4 鉄損計算}

本数値磁界解析において鉄損は次式て言十算される.

$$
P_{t}=\left|\frac{1}{\rho T} \int_{C} \dot{H} \cdot d \dot{B}\right|
$$

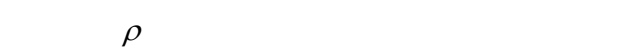

\section{5 フローチャート}

フローチャートを Fig. 3 に示す . まず磁生材料の領域には, 初 期值として磁気抵抗係数 $\bar{v}_{x r}=\bar{v}_{y r}=250$, 磁気ヒステリシス係数 $\bar{v}_{x i}=\bar{v}_{y i}=100$ を与えた . また線形領域である空気領域とコイル 領域には真空の透磁率を与えた . 本手法では, 有限要素法を用い て磁気ベクトルポテンシャルを導出し, 磁気ベクトルポテンシャ ルから式(15)，(16)を用いて磁束密度を計算する. として, 磁束条 件 $\left(B_{\max }, \theta_{B}, \alpha\right)$ に応じた磁気抵抗率係数 $\left(\bar{v}_{x r}, \bar{v}_{y r}\right)$, 磁気ヒス テリシス係数 $\left(\bar{v}_{x i}, \bar{v}_{y i}\right)$ をデータベースから求め, 過小緩和法を

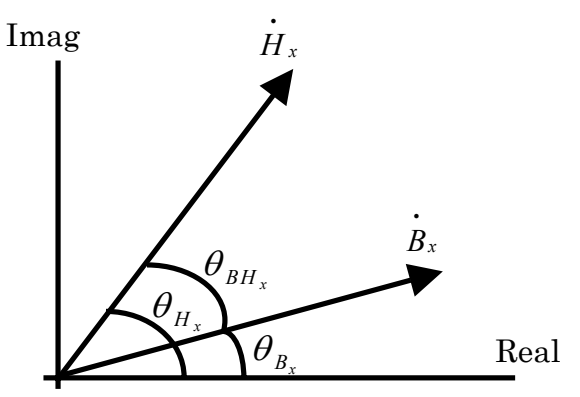

Fig. 2 Phase relationship between $\dot{B}_{x}$ and $\dot{H}_{x}$.

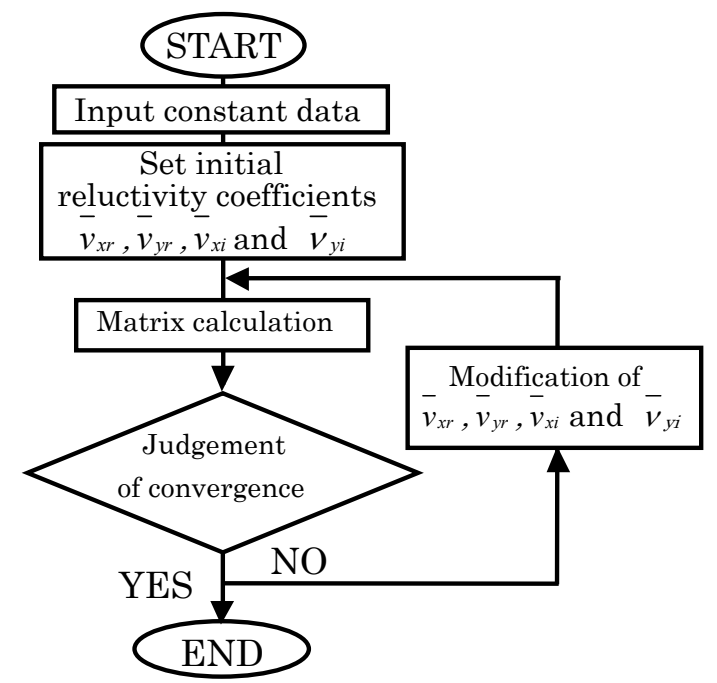

Fig. 3 Flow chart. 
用いて新しい係数に修正し, 収束条件が満たされるまで上の計 算を繰り返す．本解析ては，実部と虚部の磁気べクトルポテンシ ヤルにおける关れ光れの相対誤差が $0.1 \%$ 以下となったとき，解 か収束したと見なした。

複素 $\mathrm{E} \& \mathrm{~S}$ モデルのデータベースは, 各磁束条件下 $\left(B_{\max }, \theta_{B}\right.$, a)の磁気測定を行い, 測定結果から求められた二係数 $\bar{v}_{x r}, \bar{v}_{y r}, \bar{v}_{x i}$ ， $\bar{v}_{y i}$ が保存されている.これらの係数は，測定された正弦波磁束密 度波形と歪んた磁界強度波形の基本波成分の関係を用いて式(9)〜 式(12)より作成した .

$$
\begin{aligned}
& \dot{B}_{x}=\frac{\partial \dot{A}_{Z}}{\partial y} \\
& \dot{B}_{y}=-\frac{\partial \dot{A}_{Z}}{\partial x}
\end{aligned}
$$

\section{4. 解析結果およひ検討}

Fig. 4 に解析モデルを示す . 図(a)は概略寸法図を示し，图(b)は 局所磁気特性の検討部位を示す。解析モデルは無方向性電磁鍂岡板 の打ち抜きリングコアモデルとした . 図(a)中の矢印は電磁鋼板の 田延方向を示す.Fig. 5 にメッシュ分割图を示す.解析モデルの要 素数は 2668 , 節点数は 1335 とした。

本解析では, 励滋電源を正弦波電珐源とし，端子電珐法を考慮 して解析を行った ${ }^{6)}$.7). Fig. 6 〜 Fig. 8 に磁束密度分布, 磁界強 度分布およひ鉄損分布を示す. Fig. $6 \sim$ Fig. 8 において, 図(a)は 複素E\&Sモデルの結果 図(b)は従来のE\&S モデルの結果である。

まず,複素 E\&S モデルの解析結果について検討する。磁束密度 分布を示す Fig. 6 (a)によれば, 上下部分の内側におけるる磁束密度

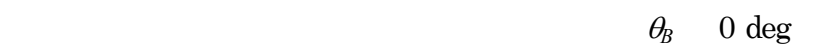
ある上下部分の場合は磁気抵抗力小さく, 磁路長の影響力強く出

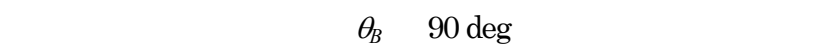
磁気抵抗力大きくなるのて磁路長の影響力出にくくなっている. 磁界強度分布を示す Fig. 7 (a)によれば, $\theta_{B}=90 \mathrm{deg}$ 付近である 左右部分では, 磁界強度か大きくなっていることか確忍できる。 これは, 磁化困難軲方向に磁束を流すため大きな磁界強度力必要 となり, $\theta_{B}=0 \operatorname{deg}$ の場合よりも $\theta_{B}=90 \operatorname{deg}$ の場合にて磁抵 抗力大きくなることが原因として考えられる 鉄損分布を示すFig. 8 (a)によれば, 鉄損分布は磁路長力短い内側付近力高くなってい ることか汾かる.以上の結果から，通常の直交異方性的取り扱い で方向性磁生材料内の 2 次元磁気特性表現できないが ${ }^{8)}$, 複素 E\&S モデルを考慮した磁界解析ては2 2次元磁気特性を考慮するこ とが可能で, 磁束密度と磁界強度のベクトル関係から直接鉄損分 布を解析することかできる数值モデルであるといえる . また今回 の解析結果より明らかのように, 無方向電磁鋼板であって も圧延方向に磁気異方性が存在するので, 正確な磁界解析 を行うためには 2 次元ベクトル磁気特性を考慮する必要が あるといえる .

次に, 複素 $\mathrm{E} \& \mathrm{~S}$ モデルと従来の E\&S モデルの解析結果の比較 を行う. 両モデルの磁束密度分布を比較すると, 磁束密度の值, 磁束力集中する箇所などの傾向がとんど一致した . 磁界強度分 布・鉄損分布は、計算值の大きさか複素 $\mathrm{E} \& \mathrm{~S}$ モデルの方で小さく なったが, 傾向は良く一致した、計算値がささくなった原因は，
複素近似法を利用するために磁界強度波形の歪みを無視して正弦 波近似したためと考えられる.正弦波近似したことにより，Fig. 9 の例のように, 最大磁束密度付近のヒステリシス軌跡湾化し， ヒステリシスループガ描く面積に差異カ泩じたため, 複素 E\&S モ デルにより求められた鉄損力゙促来の $\mathrm{E} \& \mathrm{~S}$ モデルにより求められ た鉄損に対して低〈評価されたということである。

次に , Fig. 10 に , Fig.4 (b)に示した点 (point A,B,C) の局所ヒ ステリシスループの比較結果を示す.複素 E\&S モデルは磁束密度 およひ磁界強度を正弦波と見なしているためヒステリシスループ は楕円となっており，従来のE\&S モデルで求めたヒステリシス軌 跡と形は異なるが, 両分布の傾向はよく一致していることが分か る.すなわち，X方向とY方向のヒステリシス軌跡の大きさを比 較することはできるが, 磁束密度力飽和する点や残留磁化を正し く解析することはできないということである.このため,最大磁 束密度分布の差以上に磁界強度, 鉄損分布の差の方か大きくなっ ている.しかし，最適設計問題等に適用するための精度は十分に 得られている.Fig. 11 に従来の E\&S モデルを用いて計算した鉄 損值と複素 E\&S モデルを用いて計算した鉄損值の比較結果を示 す.値は従来のE\&S モデルの值を基準に何\%大きくなったかを示 している.図の樣に $1.4 \mathrm{~T}$ 以下の磁束密度領或であれば,同一磁束 条件における相対誤差は1％以下であり実用上問題なく適用でき るが, $1.4 \mathrm{~T}$ 以上になると誤差か急激に大きくなり複素近似去 $(j \omega$ 法)て表現するのは困難となる．

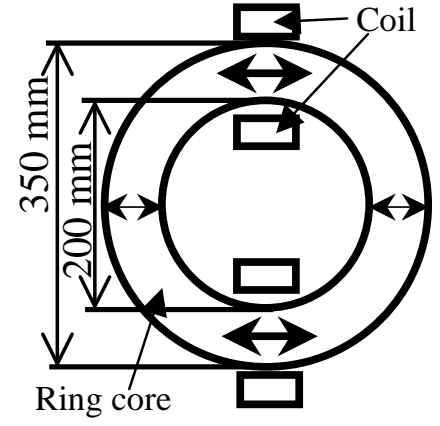

(a) Schematic diagram

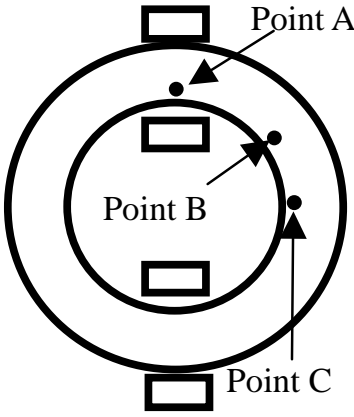

(b) Compared points
Rolling direction

Fig. 4 Ring core model for analysis.

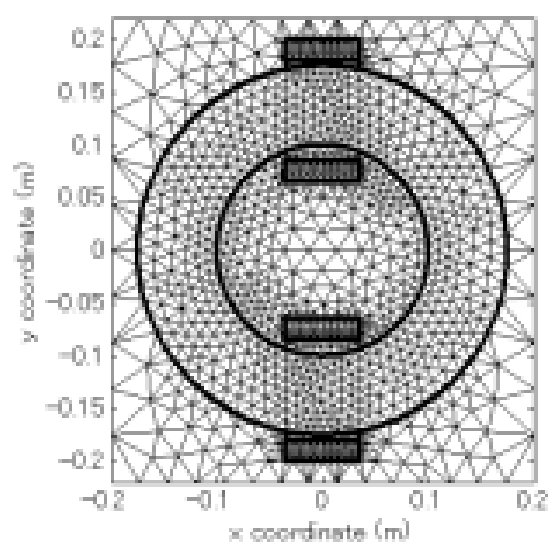

Fig. 5 Illustration of mesh division. 


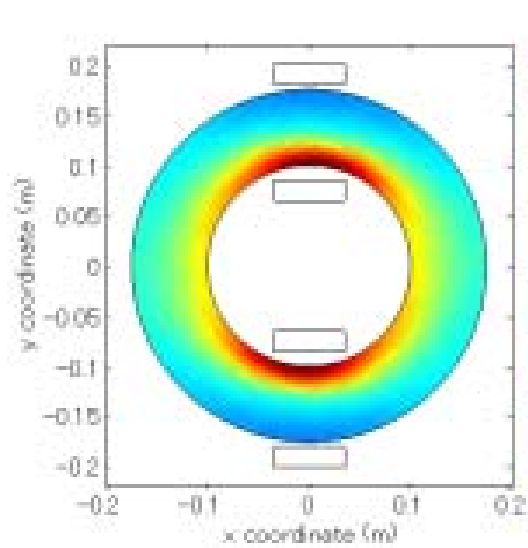

(a) Complex E\&S model

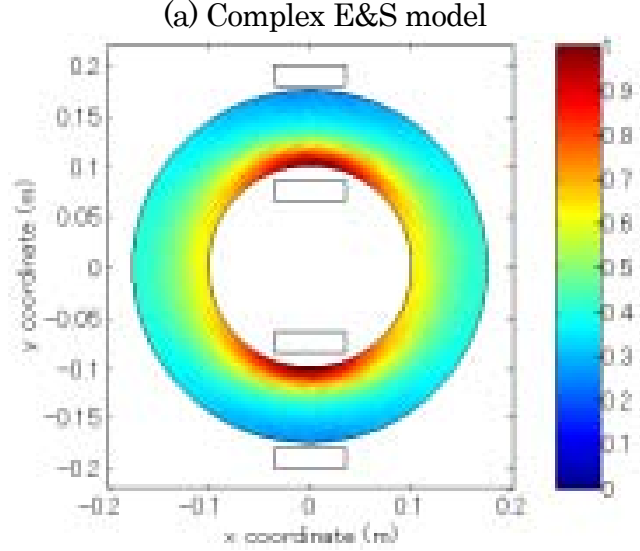

(b) Conventional E\&S model

Fig. 6 Flux density distributions.
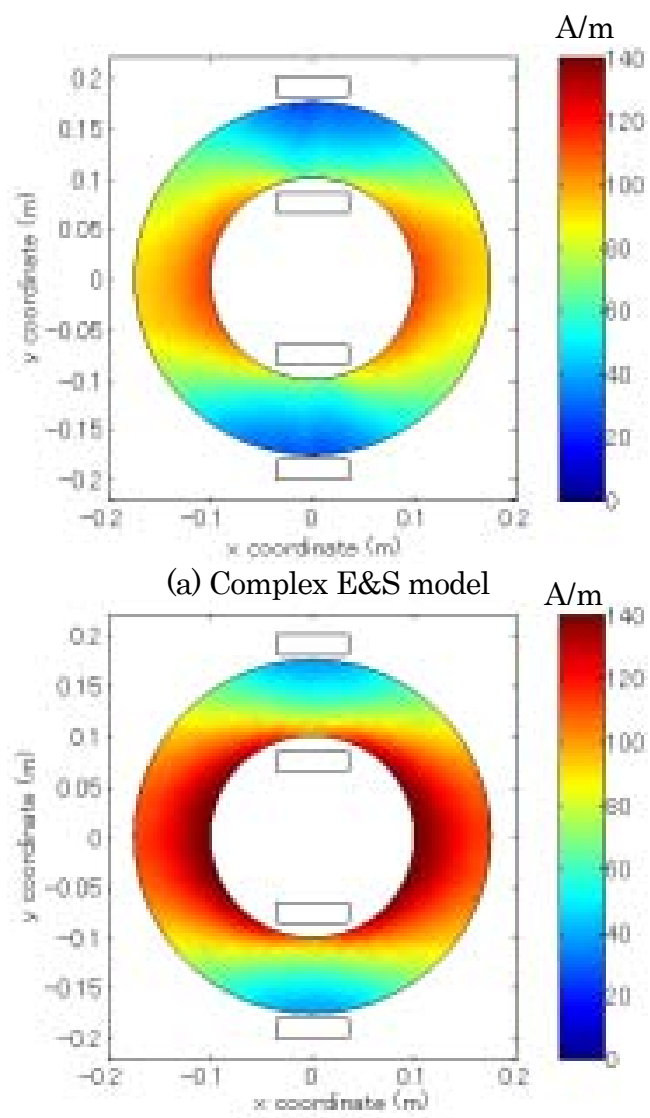

(b) Conventional E\&S model

Fig. 7 Field strength distributions.

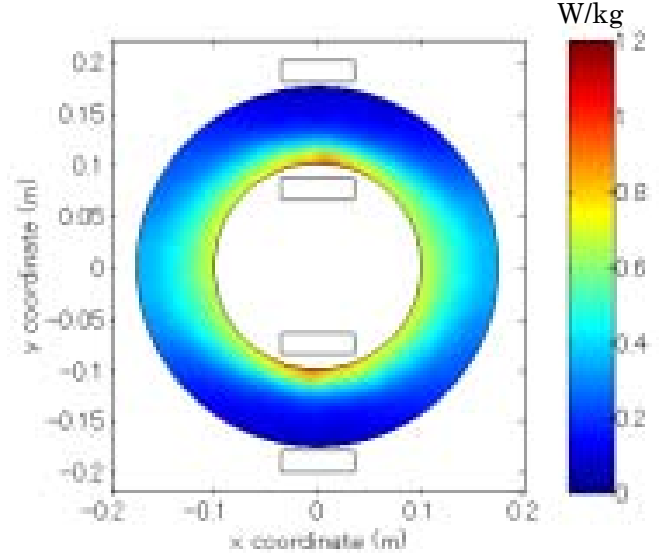

(a) Complex E\&S model

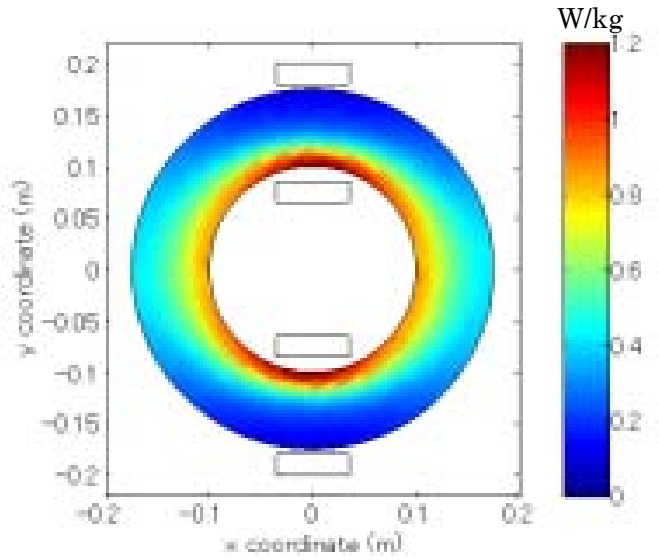

(b) Conventional E\&S model

Fig. 8 Iron loss distributions.

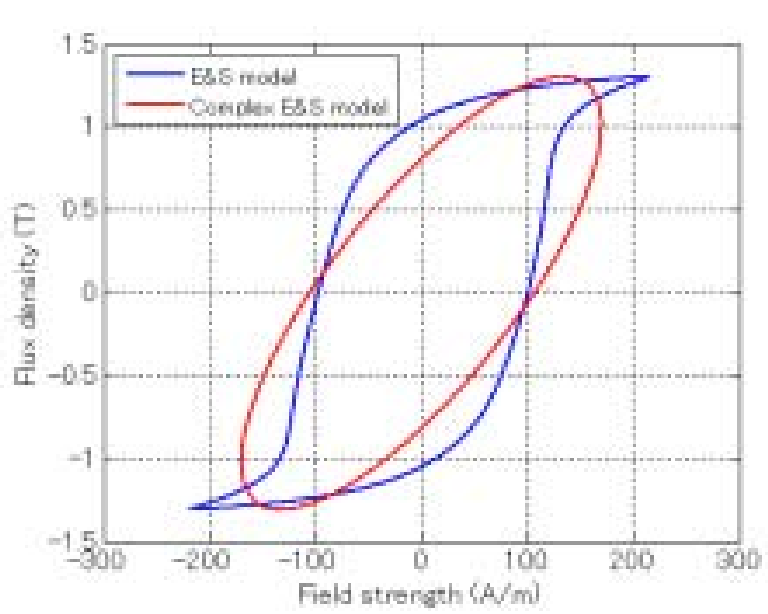

Fig. 9 Hysteresis loci.

最後に複素 $\mathrm{E} \& \mathrm{~S}$ モデルと従来の $\mathrm{E} \& \mathrm{~S}$ モデルの解析時間の比較 を行った解析には,CPU Pentium IV 3.4GHzのPCを用いた。 リングコアモデル解析において , 従来の E\&S モデルては 15〜16 時間の解析時間であったのに対して, 複素 E\&S モデルでは約 30 分て解析することかでき，約 $1 / 30$ の大幅な解析時間の短縮を可能 にした.以上から,複素E\&S モデルは簡易的に短時間て近似解が 求まる手法であり，2次元ベクトル磁気特性を考慮した高速な磁 界解析を行う手法として，有効に使用できる。 


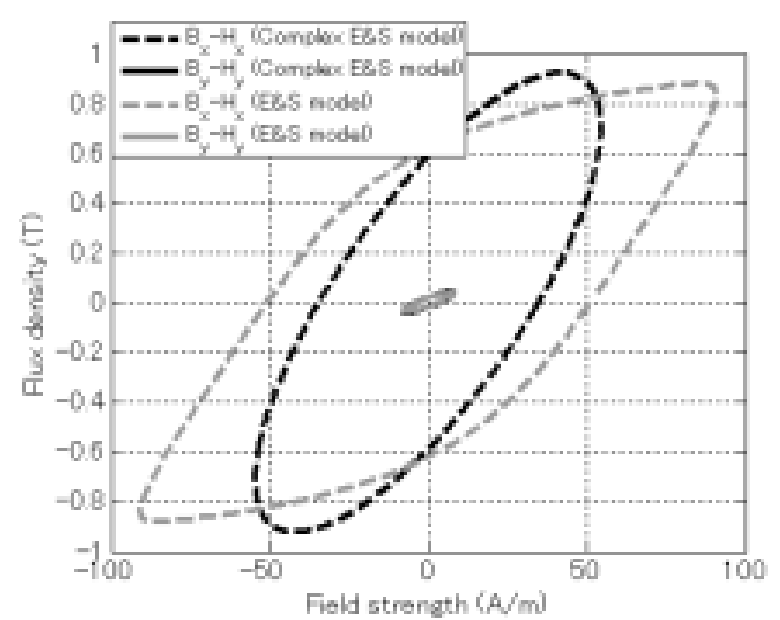

(a) Point A

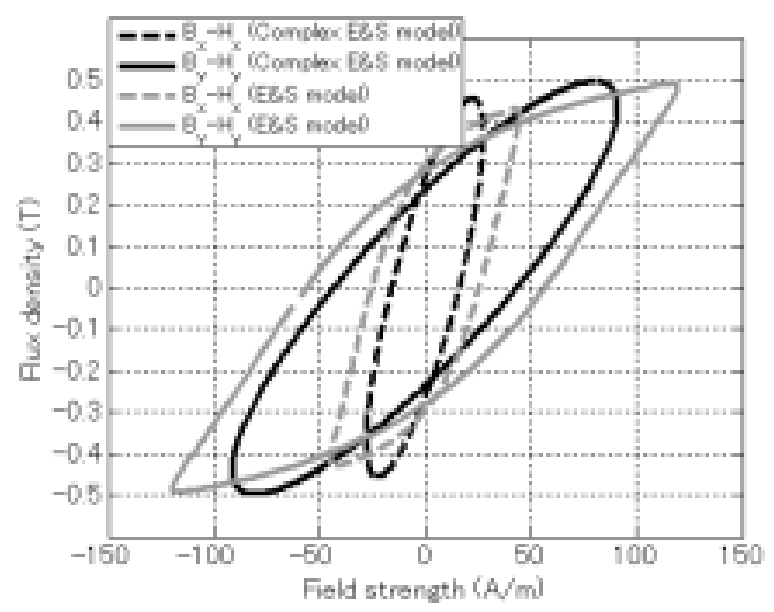

(b) Point B

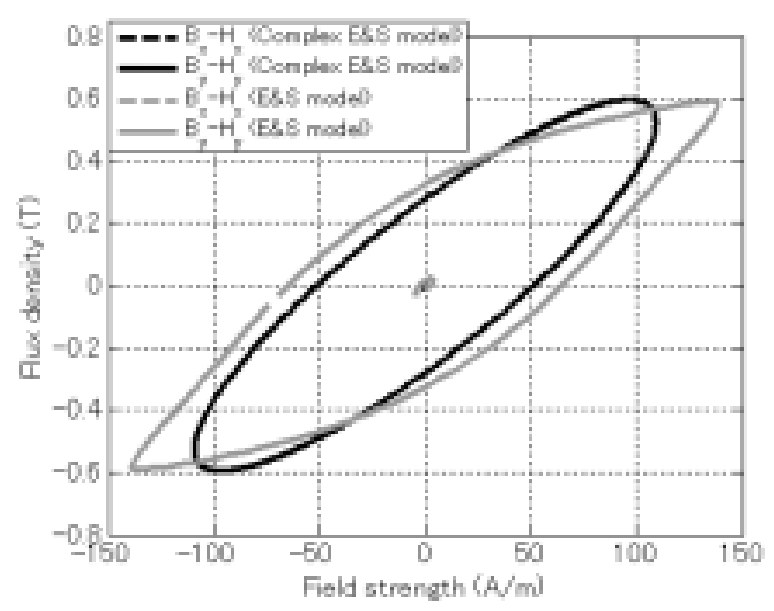

(c) Point C

Fig. 10 Hysteresis loci in local regions.

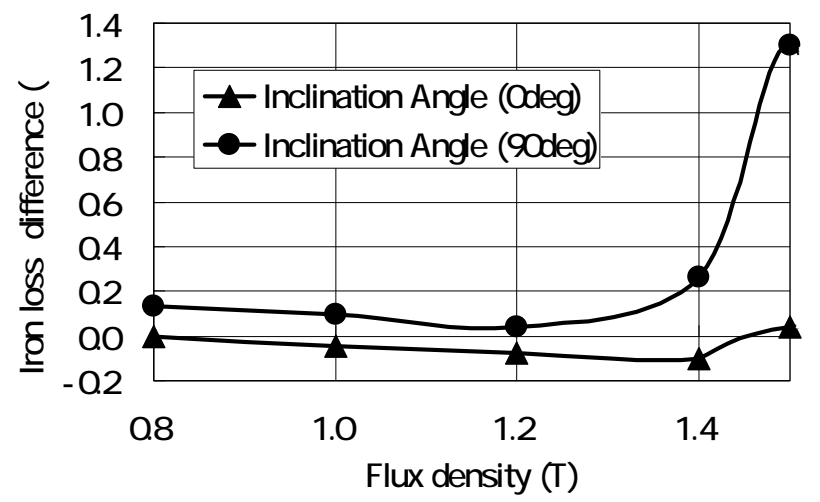

Fig. 11 Iron loss difference.

\section{5. まとめ}

本論文では, 従来の $\mathrm{E} \& \mathrm{~S}$ モデルに複素透磁率の表現を 取り入れた複素近似による解析手法を開発し，兴の妥当性 を検証した．以下に結果をまとめる．

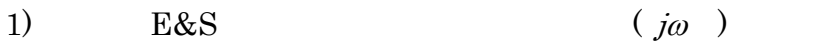
した定式化を示した .

2）実験データから求めた最大磁束密度, 傾き角を考慮した 磁気抵抗係数と磁気ヒステリシス係数を用いることによ り 2 次元ベクトル磁気特性を考慮した磁界解析が可能と なった。

3）複素 E\&S モデルを用いることで, 従来の E\&S モデルに比 べ, 大幅な解析時間を短縮することが可能であることを 明らかにした。

\section{References}

1) M. Enokizono: Journal of the Magnetics Society of Japan., Vol.27, No.2, p.50-58. (2003).

2) M. Enokizono and T. Amano: Journal of the Magnetics Society of Japan., Vol.25, p.1107-1110. (2001).

3) N. Soda and M. Enokizono: IEEE Transactions on Magnetics., Vol.36, No.4, p.1285-1288. (2000)

4) N. Soda and M. Enokizono: Journal of the Magnetics Society of Japan., Vol.24, p.827-830. (2003).

5) J.Sievert,One- and Two-dimensional Magnetic Phenomena in Electrical Steel and their Measurement, Advanced Computational and Design Techniques in Applied Electromagnetic Systems (ed. S.-y.Hahn, Elsevier Science B.V., pp.639 645. (1995).

6) S. Urata, T. Todaka, S. Shimoji, M. Enokizono: Journal of the Magnetics Society of Japan., Vol.29, No.3, p.320-325. (2005).

7) T. Nakata, and N.Takahashi: IEEE Trans. on Magn., Vol.18, No.2, p.325-330. (1982).

8) T.Nakata, N.Takahashi, K.Fujiwara, M.Nakano and N.Okamoto: IEEE Trans. on Magn., Vol.35, No.5, p.3395-3998. (1994).

2005 年 10 月 19 日受理， 2006 年 01 月 16 日採録 